Original Article

\title{
INJURIES OF WORKER BEES (APIS MELLIFERA CARNICA) STORED IN OWN AND STRANGER QUEENRIGHT COLONIES
}

\author{
Barbara Zajdel* \\ Jakub Gąbka \\ Zygmunt Jasiński \\ Zbigniew Kamiński \\ Beata Madras-Majewska \\ Apiculture Division, Faculty of Animal Science, \\ Warsaw University of Life Sciences, Nowoursynowska 166, 02-787 Warsaw, Poland \\ *corresponding author: bzajdel@oz.pl \\ Received 10 December 2013; accepted 07 August 2014
}

\begin{abstract}
A b s t r a c t
This research was conducted in 2008 and 2010 in the experimental apiary of the Warsaw University of Life Sciences. Worker bees were stored in transport cages in their own colonies and stranger colonies. The number of injuries and the death rate were checked twice, after 3 and 7 days of storage. In total, 6720 bees were examined (3360 workers from their own colonies and the same number from stranger colonies). The number of injured and dead workers had an exponential distribution (skewness>1). The worker bees sustained significantly more leg injuries (missing leg segments - $92-96 \%$ ) than injuries of arolia (13 - 15\%), wings (1 - 7\%) or antennae $(1-2)$. Worker bees stored in stranger colonies were injured significantly more frequently than worker bees stored in their own colonies. A significantly greater number of bees died in stranger colonies than in own colonies. The fact that bees stored in own colonies were injured proves that, even if they have the same smell, bees kept in cages provoke aggressive behavior from bees belonging to the banking colony.
\end{abstract}

Keywords: Apis mellifera carnica, cage, injuries, mortality, storage, worker bees.

\section{INTRODUCTION}

Queens stored in queenless colonies, called "queen banks", are often injured by bees from those colonies (Woyke et al., 1956, Jasiński, 1984; 1986; 1987; Woyke, 1988). The most common injuries among queens are leg injuries (Jasiński and Fliszkiewicz, 1995), which may be related to secretion from the tharsal gland, which inhibits the construction of queen cells (Lensky and Slabesky, 1981). The legs of some queens are paralyzed (Gerula and Bieńkowska, 2002; Gerula, 2004). Missing leg segments or whole legs make it difficult for queens to walk, injured wings preclude them from flying, and missing antennae or antenna fragments restrict the queens' sensory abilities (Jasiński, 1995).

Storing a small number of queens (3 - 4) in a bee colony, even for a short period of time, does not exclude the possibility of their being injured by bees (Woyke et al., 1956, Jasiński, 1988, Jasiński and Fliszkiewicz, 1997). Studies indicate that worker bees attending the queens are injured in a similar manner (Jasiński and Kawecki, 1992; Jasiński and Fliszkiewicz, 1997).

Bees attending the queens in cages should be in good condition, as it is their role to ensure that the queens empty their oviducts after insemination. Body injuries may deteriorate the condition and increase the mortality of bees, which in turn lowers the quality of nursing for the queens.

Worker bees enclosed in cages without queens and stored in queenless colonies are injured by bees from the nurse colonies (Madras-Majewska, 2009). Preliminary research has confirmed that worker bees in queenright colonies are also injured, regardless of whether they are stored in own or stranger colonies. Their own bees sustain injuries when kept in cages, which proves that although they may share the same smell, they are still attacked by bees from their own colony (Zajdel et al., 2009). Bees kept in cages provoke aggression from bees belonging to the banking colony (Madras-Majewska, 2009; Zajdel et 
al., 2009). The purpose of this investigation was to ascertain and compare body injuries and the death rate of workers stored in their own colonies and in stranger colonies.

\section{MATERIAL AND METHODS}

This research was conducted in 2008 and 2010 in the experimental apiary of the Apiculture Division at the Warsaw University of Life Sciences. Thirty-five colonies of Carniolan bees (Apis mellifera carnica) of medium strength with young, egg-laying queens (6 - 7 brood combs, $10-12$ combs occupied by bees) were selected from the apiary for the experiment. One-half of the worker bees used in this study were categorized as own workers (OW) that originated from their own colonies; the other half were categorized as stranger workers (SW) that originated from colonies other than the banking colony. In total, 6720 bees were examined $(n=33600 \mathrm{~W}$ and $n=3360 \mathrm{SW})$. Worker bees were obtained directly from colonies' external combs and placed in plastic transport cages (Fig. 1). Each cage had two chambers for bees $(3.5 \times 4 \mathrm{~cm})$; the food chamber $(2.5 \times 3.5 \mathrm{~cm})$ was filled with "bee candy", which served as food for the bees. One side of each cage had 27 slides $(1 \times 9 \mathrm{~mm})$. Six workers, originating from their own or a stranger colony, were placed in each cage. Cages containing bees were located in banking frames (Fig. 2). Each frame held 16 cages containing $\mathrm{OW}$ or $\mathrm{SW}$. The banking frames with cages were placed between the brood combs of the banking colonies. Two banking frames, one containing OW and the other containing SW, were placed in each colony. The number of injuries and the death rate in each cage were checked once after 3 days and again after 7 days of storage. During the first check (after 3 days), bees from the cages were anaesthetized with carbon dioxide (maximum duration of the anaesthesia was $1 \mathrm{~min}$ ). The legs, antennae, and wings of anaesthetized bees were examined under a stereoscopic microscope with a variable magnification range of $10-16 \times$. All injuries to these body parts were recorded as follows: missing foot and antenna segments, black arolia, missing arolia and claws, and frayed wing edges. After the first examination, the

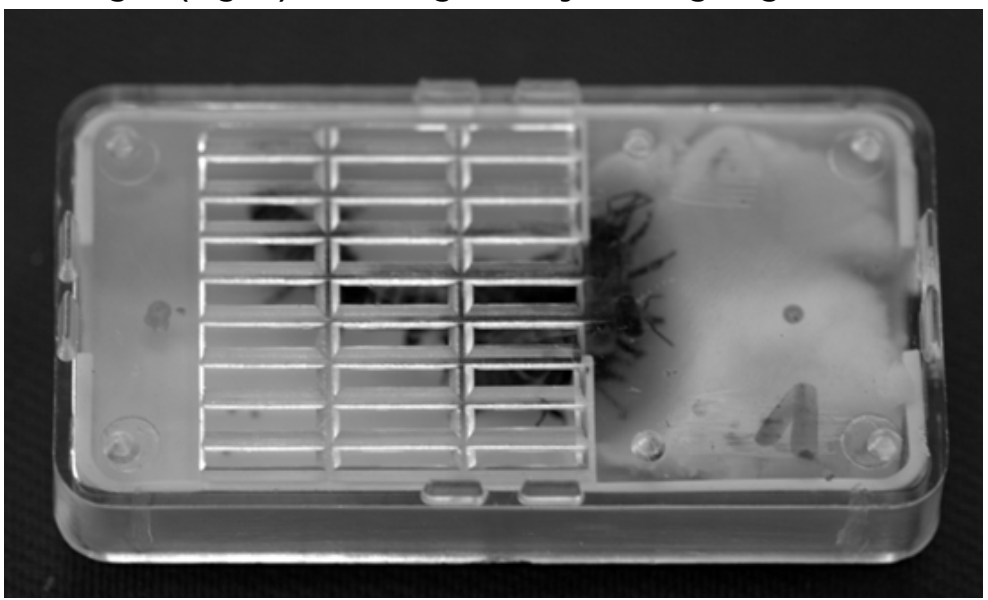

Fig. 1. A cage containing six worker bees and "bee candy".

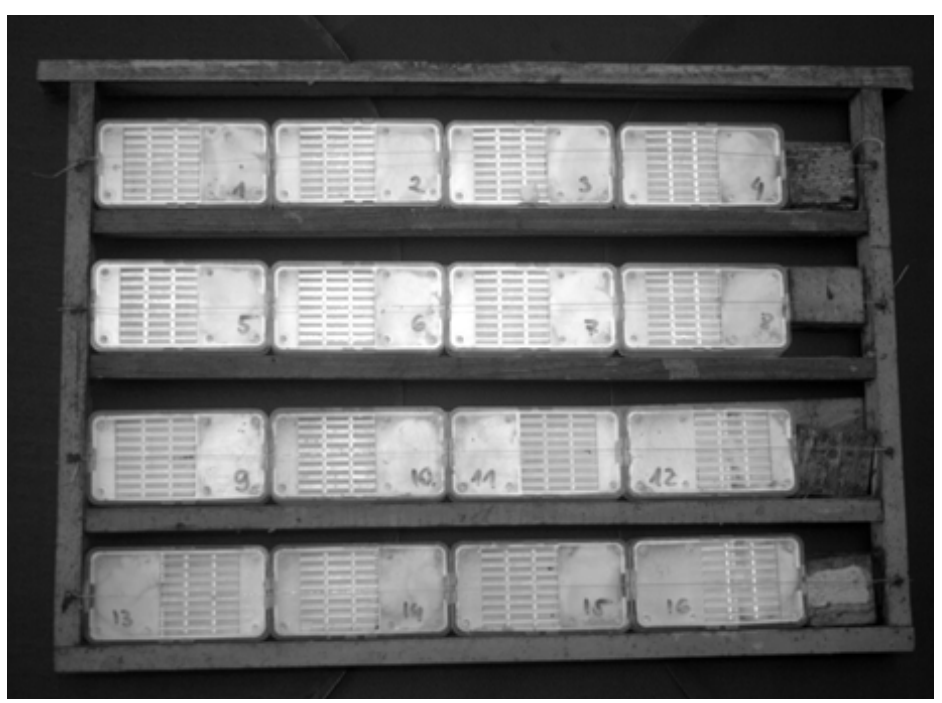

Fig. 2. The "banking frame" for 16 cages. 
bees were returned to the cages and placed in the same nurse colonies for 4 additional days.

SPSS 17 was used to conduct statistical analyses. We used Kolmogorov-Smirnov and Shapiro-Wilk tests to determine whether or not the distributions of data were normal. We employed non-parametric $\chi^{2}$, Kruskal-Wallis, and Mann-Whitney $U$ tests for independent samples, and the Wilcoxon test for two related samples $(P \leq 0.05)$. We compared mean rankings of data between groups. The mean rankings of the numbers of injured and dead bees, respectively, were calculated for cages with at least one injured or dead bee.

\section{RESULTS}

Percentage of cages with injured worker bees. SW were more aggressive towards the stored bees than OW. A significantly higher percentage of cages containing SW than containing $\mathrm{OW}$ resulted in injured bees, both after 3 days (OW: 9.5\%, SW: 25.4\%;
$\mathrm{P}<0.01, \chi^{2}$ test) and after 7 days (OW: $25.7 \%$, SW: $40 \% ; P<0.01, \chi^{2}$ test) (Fig. 3).

Distribution of the number of injured bees. The distribution of the number of injured worker bees (OW and SW stored for 3 and 7 days) did not approach a normal distribution (Kolmogorov-Smirnov test and Shapiro-Wilk test, $\mathrm{P}<0.001)$; however, it displayed high skewness (1.77 - 2.40; Tab. 1). The distribution of the number of injured OW and SW was most similar to the right-asymmetric exponential distribution curve (Fig. 4, thin curve). To draw an exponential curve that is a better fit to the histogram, the median was used instead of the mean (Fig. 4, bold curve).

Effect of storage time on injuries. The number of injured workers after 7 days of storage ranked significantly higher than the number of injured workers after 3 days of storage, in both own colonies (Wilcoxon, $\mathrm{Z}=-2.81, \mathrm{~N}=53, \mathrm{~N} 2=145$;

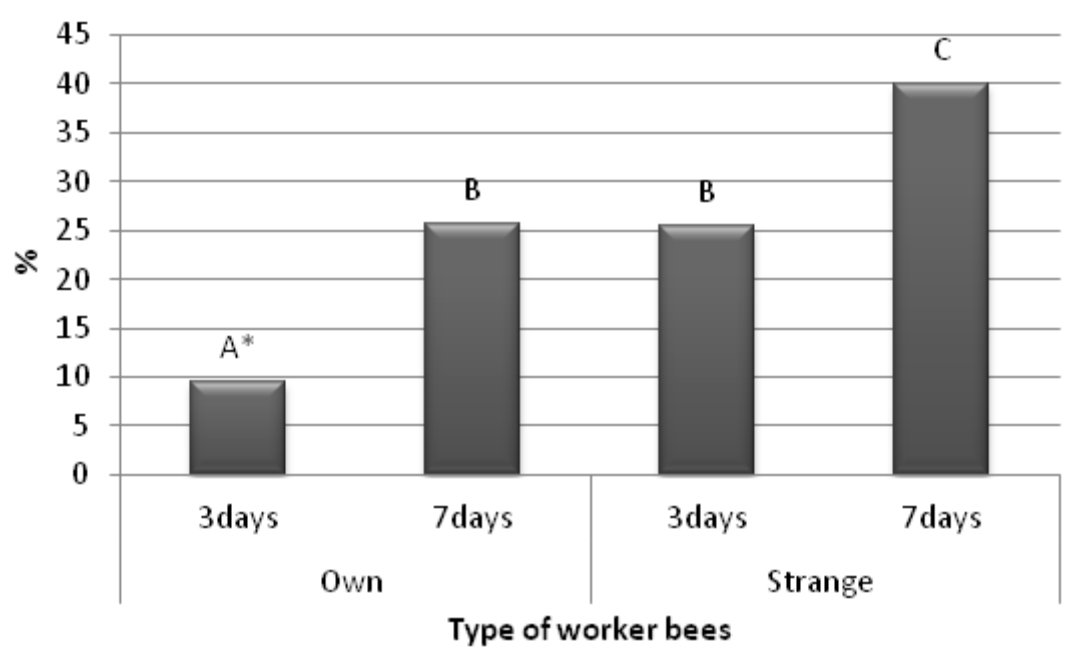

Fig. 3. Percentage of cages with injured worker bees after storage in own and stranger colonies for 3 and 7 days, respectively.

*Different letters indicate significant differences between mean rankings in individual groups ( $\chi^{2}$ test, $\left.P<0.01\right)$.

Table 1.

The number of injured worker bees stored in own colonies or stranger colonies

for 3 and 7 days, respectively, calculated per cage

\begin{tabular}{ccccccccc}
\hline $\begin{array}{c}\text { Group of } \\
\begin{array}{c}\text { worker } \\
\text { bees }\end{array}\end{array}$ & $\begin{array}{c}\text { No of } \\
\text { days } \\
\text { stored }\end{array}$ & $\begin{array}{c}\text { No of } \\
\text { cages }\end{array}$ & $\begin{array}{c}\text { Min-Max } \\
(\text { No) }\end{array}$ & $\begin{array}{c}\text { Min-Max } \\
(\%)\end{array}$ & Mean & Mean rankings & Median & Skewness \\
\hline \multirow{2}{*}{ Own } & 3 & 53 & $1-3$ & $16.7-50$ & 1.21 & $246.08 \mathrm{~A}^{\star} \mathrm{a}^{\star \star}$ & 1 & $2.40 \pm 0.3$ \\
\cline { 2 - 9 } & 7 & 145 & $1-5$ & $16.7-83.5$ & 1.34 & $266.91 \mathrm{~B} \mathrm{a} \mathbf{a}^{\star \star *}$ & 1 & $2.40 \pm 0.2$ \\
\hline \multirow{2}{*}{ Stranger } & 3 & 143 & $1-3$ & $16.7-50$ & 1.28 & $263.14 \mathrm{Ab}$ & 1 & $1.77 \pm 0.2$ \\
\cline { 2 - 9 } & 7 & 221 & $1-6$ & $16.7-100$ & 1.60 & $306.20 \mathrm{~B} \mathrm{~b}$ & 1 & $1.83 \pm 0.2$ \\
\hline
\end{tabular}

Different letters indicate significant differences between mean rankings in individual groups (Kruskal-Wallis ${ }^{\#}$ test $P<0.05$; pairwise comparisons Mann-Whitney U test, $P<0.05$; or Wilcoxon test, $P<0.01$ ):

$A^{*}$ (CAPITALS), comparison of rankings in the same group of bees after 3 and 7 days of colony storage.

$a^{\star \star}$ (small letters), comparison of rankings in different groups of bees after 3 days of storage in a colony

$a^{\star \star \star}$ (small bold letters), comparison of rankings in different groups of bees after 7 days of storage in a colony. 
A. Own worker bees

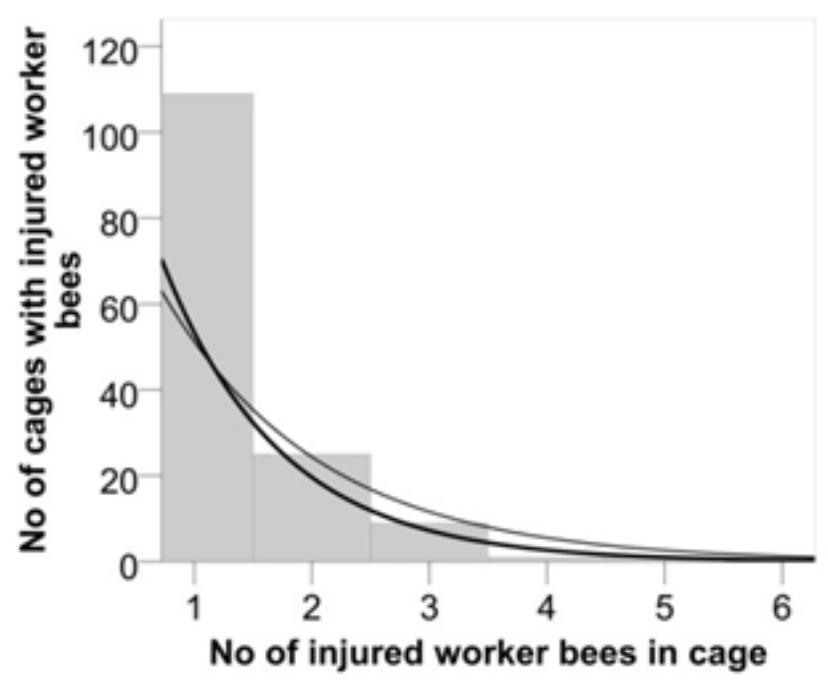

B. Stranger worker bees

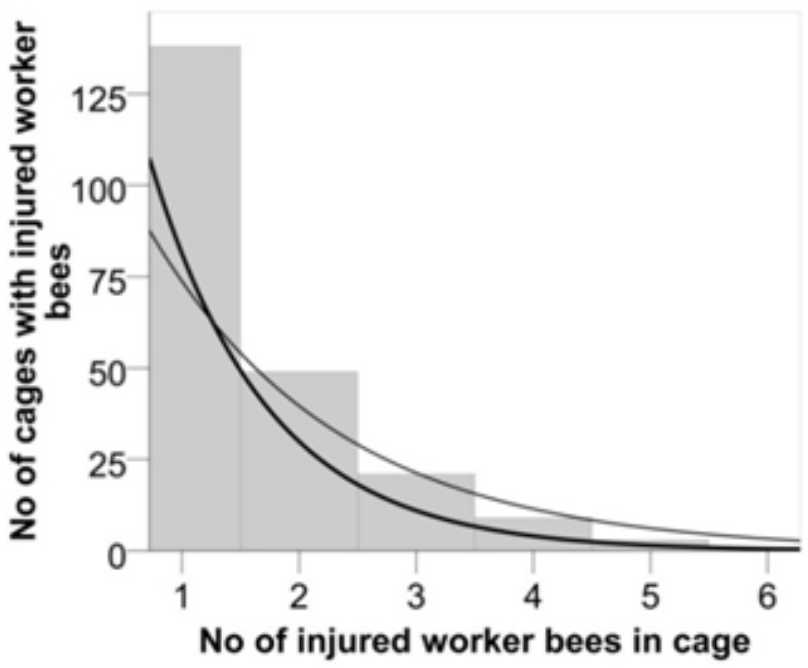

Fig. 4. Distribution of injured worker bees stored for 7 days in own (A) and stranger colonies (B). The curves represent exponential distribution. The thin line represents a curve with the mean of data. The bold line represents a curve in which the mean was replaced by the median of data (median=1). The bold curve provides a better fit to the data.

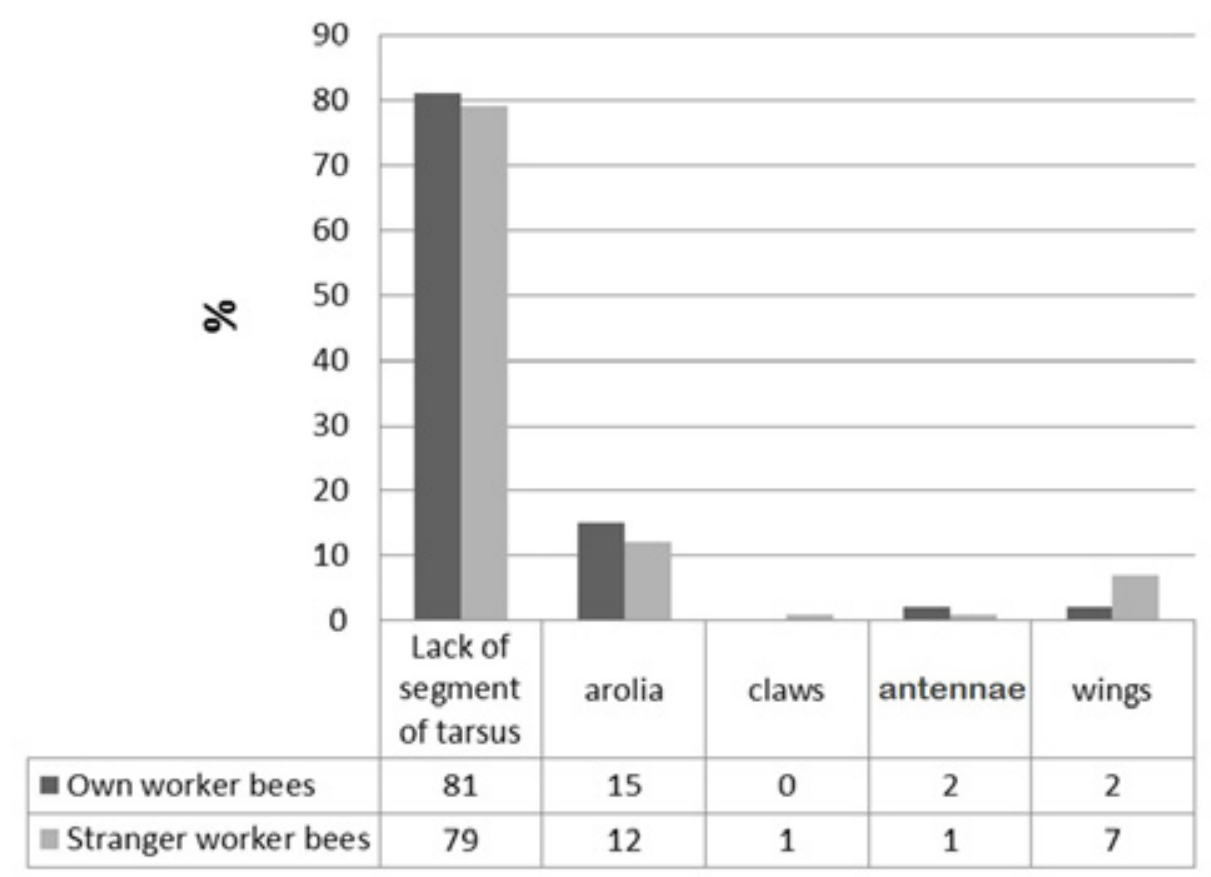

Fig. 5. Percentages of injury types among worker bees (in cages with injured bees) stored for 7 days in own colonies or stranger colonies.

$P<0.00$ ) and stranger colonies (Wilcoxon, $Z=-5.68$, $\mathrm{N} 1=143, \mathrm{~N} 2=221 ; \mathrm{P}<0.00)($ Tab. 1$)$.

Types of injuries and their frequency. We observed 10 different types of injures in own colonies, and 11 in stranger colonies. Bees from banking colonies that were injured during 7 days of storage most frequently lack of segments of the tarsus (OW: $81 \%$, SW: $79 \%$ ) as well as the arolia (OW: $15 \%$, SW: $12 \%$ ). Other types of injuries (antennae and wings) were rare (Antennae: OW: 2\%, SW: 7\%; Wings: OW: 2\%, SW:
1\%). We observed missing claws in SW only (1\%; Fig. 5).

Injuries to all leg pairs were represented among bees stored in colonies. Injures to the second and third leg pairs of OW were 1.2-fold more frequent than injuries to the first leg pair (Kruskal-Wallis test, $P<0.01$; pairwise comparisons Mann-Whitney $U$ test, $P<0.00$ ) (Tab. 2). In SW, we observed injuries to the three respective leg pairs at similar frequencies.

In some cases, workers stored in colonies had all 
tarsus segments or an entire leg torn off. OW had tarsus segments torn off significantly more rarely than other segments (Kruskal-Wallis test, $\mathrm{P}<0.01$; pairwise comparisons Mann-Whitney U test, $P<0.01$ ), while SW lost four segments more often than they lost five or three segments (Kruskal-Wallis test, $P<0.01$; pairwise comparisons Mann-Whitney U test, $P<0.00)$.

A black arolium and missing arolia were observed in both groups of worker bees, while missing claws were only observed in the SW group (Tab. 3). In some cases, the first wing pair was injured. Wing injuries consisted of tears to the external edge (probably as a result of the wing edge being caught by the mandibles of bees from the banking colonies). Injuries to the antennae consisted of the loss of several segments of the antennal flagellum. The above injuries were rare, and no differences in frequency were observed between OW and SW (Tab. 3).

Death rate during storage. The numbers of dead OW and SW did not approach a normal distribution (Kolmogorov-Smirnov test and Shapiro-Wilk test, $P \leq 0.00)$. Skewness was high (1.10 - 1.55) and gave the exponential distribution rightward asymmetry (Tab. 4).

At both 3 and 7 days of storage, the number of dead workers ranked significantly higher in stranger colonies than in own colonies (Mann-Whitney $\mathrm{U}$ test $\mathrm{P}<0.00$; Tab. 5). The number of dead workers ranked significantly higher after 7 days of storage than after 3 days of storage in both own colonies (Wilcoxon, $\mathrm{Z}=-5.41, \mathrm{~N} 1=92, \mathrm{~N} 2=184 ; \mathrm{P}<0.00)$ and stranger colonies (Wilcoxon, $\mathrm{Z}=-7.19, \mathrm{~N} 1=146$, $\mathrm{N} 2$ = 208; $\mathrm{P}<0.00)($ Tab. 4).

Table 2.

The number of worker bees that sustained injuries to different pairs of legs while stored in 548 cages for 7 days in own colonies or stranger colonies, calculated per cage

\begin{tabular}{|c|c|c|c|c|c|c|c|c|c|c|}
\hline \multirow{4}{*}{$\begin{array}{c}\text { Pair of } \\
\text { legs }\end{array}$} & \multicolumn{10}{|c|}{ Worker bees with injured legs } \\
\hline & \multicolumn{5}{|c|}{ Own } & \multicolumn{5}{|c|}{ Stranger } \\
\hline & \multirow{2}{*}{$\begin{array}{l}\text { No of } \\
\text { cages }\end{array}$} & \multirow{2}{*}{$\begin{array}{c}\text { No of } \\
\text { legs }\end{array}$} & \multicolumn{2}{|c|}{ Mean } & \multirow{2}{*}{$\begin{array}{c}\text { Mean } \\
\text { rankings }\end{array}$} & \multirow{2}{*}{$\begin{array}{l}\text { No of } \\
\text { cages }\end{array}$} & \multirow{2}{*}{$\begin{array}{c}\text { No of } \\
\text { legs }\end{array}$} & \multicolumn{2}{|c|}{ Mean } & \multirow{2}{*}{$\begin{array}{c}\text { Mean } \\
\text { rankings }\end{array}$} \\
\hline & & & No & $\%$ & & & & No & $\%$ & \\
\hline $1^{\text {st }}$ & 57 & 65 & 1.1 & 18.3 & $223.74^{\#} a^{\star}$ & 96 & 142 & 1.5 & 25.0 & $283.39 a$ \\
\hline $2^{\text {nd }}$ & 73 & 95 & 1.3 & 21.7 & $266.22 \mathrm{~b}$ & 127 & 177 & 1.4 & 23.3 & $277.42 \mathrm{a}$ \\
\hline $3^{\text {rd }}$ & 77 & 113 & 1.5 & 25.0 & 296.84 b & 118 & 159 & 1.4 & 23.3 & $272.35 a$ \\
\hline Total & 207 & 273 & 1.9 & 31.7 & $265.91 A^{\star \star}$ & 341 & 478 & 1.4 & 23.3 & $277.34 \mathrm{~A}$ \\
\hline
\end{tabular}

Different letters indicate significant differences between mean rankings in individual groups (Kruskal-Wallis test" ${ }^{\#} P<0.01$; pairwise comparisons Mann-Whitney $\mathrm{U}$ test, $\mathrm{P}<0.01$ ).

$a^{\star}$ (small letters), comparison of rankings in the same column.

$A^{\star \star}$ (capitals), comparison of rankings in the same line summary.

Table 3.

Types of injuries sustained by worker bees in 122 cages, calculated per cage. Injured bees were stored in own colonies or stranger colonies for 7 days

\begin{tabular}{|c|c|c|c|c|c|c|c|c|c|}
\hline \multirow{4}{*}{$\begin{array}{l}\text { Injured body } \\
\text { parts }\end{array}$} & \multicolumn{9}{|c|}{ Worker bees with injuries } \\
\hline & \multicolumn{5}{|c|}{ Own } & \multicolumn{4}{|c|}{ Stranger } \\
\hline & \multirow{2}{*}{$\begin{array}{l}\text { No of } \\
\text { cages }\end{array}$} & \multirow{2}{*}{$\begin{array}{l}\text { No of } \\
\text { body } \\
\text { parts }\end{array}$} & \multicolumn{2}{|c|}{$\begin{array}{l}\text { Mean per } \\
\text { cage }\end{array}$} & \multirow{2}{*}{$\begin{array}{c}\text { Mean } \\
\text { rankings }\end{array}$} & \multirow{2}{*}{$\begin{array}{l}\text { No of } \\
\text { cages }\end{array}$} & \multirow{2}{*}{$\begin{array}{l}\text { No of } \\
\text { body } \\
\text { parts } \\
\end{array}$} & $\begin{array}{l}\text { Mean per } \\
\text { cage }\end{array}$ & \multirow{2}{*}{$\begin{array}{l}\text { Mean } \\
\text { rankings }\end{array}$} \\
\hline & & & No & $\%$ & & & & No $\%$ & \\
\hline Black arolia & 29 & 37 & 1.28 & 21.3 & 39.19\#a* & 38 & 56 & 1.4724 .5 & $44.78 \mathrm{a}$ \\
\hline Lack of arolia & 2 & 2 & 1.00 & 16.7 & $48.00 \mathrm{a}$ & 15 & 16 & 1.0717 .8 & 39.88 a \\
\hline Lack of claws & 0 & 0 & - & - & - & 6 & 6 & 1.0016 .7 & $48.00 \mathrm{a}$ \\
\hline Injury of wings & 11 & 20 & 1.82 & 31.3 & $51.14 \mathrm{a}$ & 8 & 9 & 1.1318 .8 & $28.00 \mathrm{a}$ \\
\hline $\begin{array}{c}\text { Injury of } \\
\text { antennae }\end{array}$ & 3 & 3 & 1.00 & 16.7 & $20.00 \mathrm{a}$ & 10 & 12 & 1.20 & 31.94 a \\
\hline Total & 45 & 53 & 1.2 & 23 & $39.07 A^{\star \star}$ & 77 & 99 & $1.3 \quad 21.5$ & $35.71 \mathrm{~A}$ \\
\hline
\end{tabular}

Percentage of injured bees in one cage containing six workers. Different letters indicate significant differences between mean rankings in individual groups (Kruskal-Wallis test" ${ }^{\#}<0.01$; pairwise comparisons Whitney $U$ test, $P<0.01$ ).

$a^{\star}$ (small letters) concern rankings in the same column.

$A^{\star \star}$ (capitals) concern rankings in the same line. 
Table 4.

Mortality of worker bees stored in own colonies or stranger colonies

for 3 and 7 days, calculated per cage

\begin{tabular}{|c|c|c|c|c|c|c|c|c|}
\hline $\begin{array}{c}\text { Group of } \\
\text { worker } \\
\text { bees }\end{array}$ & $\begin{array}{l}\text { No of } \\
\text { days } \\
\text { stored }\end{array}$ & $\begin{array}{l}\text { No of } \\
\text { cages }\end{array}$ & $\begin{array}{c}\text { Min - Max } \\
\text { (No) }\end{array}$ & $\begin{array}{c}\text { Min - Max } \\
(\%)\end{array}$ & Mean & Mean rankings" & Median & Skewness \\
\hline \multirow{2}{*}{ Own } & 3 & 92 & $1-5$ & $16.7-83.5$ & 1.72 & $263.49 A^{*} a^{\star \star}$ & 1 & $1.40 \pm 0.26$ \\
\hline & 7 & 184 & $1-6$ & $16.7-100$ & 1.92 & $293.03 \mathrm{~B} \mathrm{a} \mathrm{a}^{\star \star \star}$ & 1 & $1.10 \pm 0.15$ \\
\hline \multirow{2}{*}{ Stranger } & 3 & 146 & $1-6$ & $16.7-100$ & 2.24 & 320.39 A b & 2 & $1.40 \pm 0.26$ \\
\hline & 7 & 208 & $1-6$ & $16.7-100$ & 2.35 & $352.30 \mathrm{~B} \mathrm{~b}$ & 2 & $1.55 \pm 0.17$ \\
\hline
\end{tabular}

Different letters indicate significant differences between mean rankings in individual groups (Kruskal-Wallis ${ }^{\#}$ test, $P<0.01$; pairwise comparisons Mann-Whitney U test, $\mathrm{P}<0.01$; or Wilcoxon test, $\mathrm{P}<0.01)$.

$A^{*}$ (CAPITALS) concern rankings in the same group of bees after being stored in colonies for 3 and 7 days, respectively.

$a^{\star *}$ (small letters) concern rankings in different groups of bees after being stored in a colony for 3 days.

$a^{\star \star \star}$ (small bold letters) concern rankings in different groups of bees after being stored in colonies for 7 days.

\section{DISCUSSION}

It has been confirmed that worker bees stored in own colonies without a queen sustain injuries (Madras-Majewska, 2009). The preliminary research results confirmed that worker bees closed in cages in queenright colonies are also injured, regardless of whether they are stored in own or stranger colonies (Zajdel et al., 2009).

Jasiński (1995) and Jasiński and Fliszkiewicz (1995) described 26 different types of queens' injuries. Gerula (2004) distinguished 17 types. It was expected that worker bees would be injured to a lesser extent than queens, which produce pheromones and are treated worse by the nurse bees. This research has revealed only 11 types of injuries in workers. According to the classification of queens' injuries proposed by Jasiński (1984, 1987, $1995)$, the majority of injuries (64\%) were related to changes in the color of arolia, while $21 \%$ were related to arolium deformation and partial or complete loss of arolia and claws. Missing leg segments or missing whole legs accounted for only $15 \%$ of injuries. Our research also confirmed the findings of MadrasMajewska (2009): the most common injuries of bees caged in own colonies concerned legs. We observed that leg segments accounted for $80 \%$ of injuries; in comparison, 11 - $15 \%$ of injuries were to the arolium, 2 - $6 \%$ were to the wing, and $0-2.5 \%$ were to the antennae). This distribution of injury types is most likely caused by the fact that the caged bees stick their legs out through the slots. Bees from the banking colonies then jerk at the protruding legs with mandibles and tear off leg segments or injure the arolia.

Loc et. al (1996) and Wilde and Loc (1997) observed that the third and first leg pairs were injured most often in queens stored for 48 hours in queen banks. In the present study, we observed that in workers from own colonies, injuries were most often inflicted to the third and second leg pairs (34.8\% and $41.8 \%$, respectively). In workers from stranger colonies, similar proportions of all three leg pairs were injured (30 - 40\%).

The fact that bees from own colonies are injured proves that the caged bees provoke aggressive behavior from bees belonging to the banking colony, even if they share the same smell (Madras-Majewska, 2009, Zajdel et al., 2009). Stressed bees belonging to the banking colonies jerk at the protruding legs, antennae, and wings of bees kept in cages, thus causing injury to those body parts.

\section{CONCLUSIONS}

Worker bees caged in queenright colonies sustain a variety of injuries, including injuries to legs (79 - 80\%), arolia (13 - 15\%), wings (1 - 7\%), and antennae (1 - 2\%).

Injuries are inflicted regardless of whether worker bees are stored in own or stranger colonies. Workers stored in stranger colonies are injured significantly more frequently than those stored in own colonies. Storing bees in stranger colonies also results in a significantly higher mortality compared with bees stored in own colonies.

Bees enclosed in cages provoke aggressive behavior bees from bees belonging to the nurse colony, even if they share the same smell.

In order to decrease the number of injuries sustained by caged bees stored in queen banks, these bees should originate from the same colonies in which they are stored. 


\section{Ј. APPC. SCL. VOL. 58 N NO. 22014}

\section{ACKNOWLEDGEMENTS}

We wish to thank Professor Jerzy Woyke for his help with statistical analyses and revision of this manuscript.

\section{REFERENCES}

Gerula D. (2004) Powstanie uszkodzeń matek sztucznie unasienianych podczas wychowu i ich wpływ na wartość użytkową. In: Materiały z Konferencji. XLI Naukowa Konferencja Pszczelarska. Puławy - Poland. 09-10 March 2004: 18-19.

Gerula D., Bieńkowska M. (2002) Effect of injury to honeybee queens on egg laying rate and colony strength. Journal of Apicultural Science 46(1):75-83.

Jasiński Z. (1984) Badania nad uszkodzeniami matek pszczelich przechowywanych w różnych warunkach. In: Materiały z Konferencji. XX Naukowa Konferencja Pszczelarska. Puławy - Poland. 04-06 April 1884: 7-8.

Jasiński Z. (1986) Injuries of queens caged in queenless colonies. In: Proceedings of Symposium International Apimondia. Insemination scincifique et comerciale de reinesd'abeilles. Touluse - France. 12-14 May 1986: 2324.

Jasiński Z. (1987) Injuries of queens caged in queenless colonies. In: Proceedings of 31 st Internanional Beekiping Congress. Warsaw - Poland. 19-25 August 1987: $126-$ 128.

Jasiński Z. (1988) Wpływ liczby matek przechowywanych w osieroconych rodzinach pszczelich na ich uszkadzanie przez pszczoły. In: Materiały z Konferencji. XXV Naukowa Konferencja Pszczelarska. Puławy - Poland. 09-10 April 1988: 15-16.

Jasiński Z. (1995) Uszkadzanie matek pszczelich w czasie ich przechowywania. Rozprawy Naukowe i Monografie. Wyd. SGGW. Warszawa. 56 pp.

Jasiński Z., Fliszkiewicz C. (1995) Uszkodzenia matek pszczelich przechowywanych w osieroconych rodzinach w klateczkach z pszczołami i bez nich. Pszczelnicze Zeszyty Naukowe 29(2): 7-14.
Jasiński Z., Fliszkiewicz C. (1 997) Banki matek w rodzinach nieosieroconych a uszkadzania matek. In: Materiały z Konferencji. XXXIV Naukowa Konferencja Pszczelarska. Puławy - Poland. 12-13 March 1997: 16-17.

Jasiński Z., Kawecki P. (1992) Badania uszkodzeń u matek i pszczół towarzyszącym im w klateczkach przechowywanych w rodzinach z czerwiem i bez czerwiu. In: Materiały z Konferencji. XXIX Naukowa Konferencja Pszczelarska. Puławy - Poland. 08-09 April 1992: 1 1-12.

Lensky Y., Slabeski Y. (1981) The inhibiting effect of the queen bee (Apis mellifera L.) foot-print pheromone on the construction of swarming queen cups. Journal of Insect Physiology 27(5): 313-323.

Loc K., Wilde J., Loc M. (1996) Artificially inseminated honeybee queens kept ina queenless colony (queenbank).

Pszczelnicze Zeszyty Naukowe 40 (2): 145-154.

Madras-Majewska (2009) The comparison of bee workers damages in their own colonies without queen. Annals of Warsaw University of Life Science - SGGW. 46: 81-85.

SPSS 17.0 software for Windows. SPSS. Chicago, IL, USA.

Wilde J., Loc K. (1997) Wpływ uszkodzeń matek sztucznie unasienianych na wyniki poddawania i rozpoczęcie czerwienia. Annales Universitatis Marie CurieSkłodowska. Lublin-Polonia. Section DD. 52 (30): 305311.

Woyke J. (1988) Problems with queen banks. American Bee Journal 124(4): 276-278.

Woyke J., Głogowska Z., Nowosielska B. (1956) Opieka pszczół nad matkami przechowywanymi w różnych klateczkach. Pszczelarstwo 7(2): 4-9. Available at: http:// jerzy_woyke.users.sggw.pl/1956_injuries_queens.pdf

Zajdel B., Jasiński Z., Szafarska G. (2009) Injuries of honey bee workers and drones caged in native and foreign colonies. Annals of Warsaw University of Life Science SGGW 46: 135-140. 